\title{
FAKTOR-FAKTOR YANG MEMPENGARUHI KEPUTUSAN KONSUMEN MENJADI NASABAH BANK SYARIAH
}

\author{
Gede Adi Wirapradnyana \\ Jurusan Pendidikan Ekonomi, Fakultas Ekonomi dan Bisnis \\ Universitas Pendidikan Ganesha \\ Singaraja, Indonesia \\ e-mail: gwirapradnyana@yahoo.co.id
}

\begin{abstract}
Abstrak
Akhir-akhir ini ketatnya persaingan di dunia bisnis jasa perbankan antara bank konvensional dan bank syariah menuntut bank harus benar-benar mengetahui strategi yang tepat untuk memenangkan persaingan dalam menarik konsumen. Bank syariah merupakan industri jasa yang relatif baru, oleh karena itu dalam rangka meningkatkan kinerja operasionalnya, perbankan syariah berusaha untuk melayani kebutuhan masyarakat secara menyeluruh dengan menerapkan Syariah Islam di setiap aktivitas perbankannya. Bank syariah harus memperhatikan perilaku nasabahnya yang mencerminkan seseorang melakukan pembelian jasa, memilih dan membeli produk, baik yang menyimpan maupun yang meminjam, sehingga dapat meningkatkan efektifitas kinerja bank. Berdasarkan hal di atas maka pertimbangan yang dapat dijadikan pedoman dalam menentukan keputusan konsumen menggunakan jasa adalah kualitas pelayanan, untuk mengukur kualitas pelayanan sebagai dasar pengukuran konsumen dalam menggunakan jasa yaitu bukti fisik, empati, keandalan, ketanggapan dan jaminan serta hal-hal yang penting dalam penentuan keputusan konsumen memilih jasa perbankan.
\end{abstract}

Kata Kunci : keputusan konsumen menjadi nasabah

\begin{abstract}
Recent competition of business banking services between conventional banks and Islamic banks requires banks must really know the right strategy to win the competition in attracting consumers. Islamic bank is a relatively new service industry, therefore in order to improve operational performance, Islamic banking seeks to serve the needs of sweeping society by implementing Islamic Sharia in all its banking activities. Islamic banks should pay attention to its customers which reflect the behavior of a person making a purchase services, choose and buy the product, both the store and the borrowing, so as to improve the effectiveness of the bank's performance. Based on the above, there are considerations that can be used as guidelines in determining the consumer's decision to use the services is the quality of the service, to measure the quality of service as a basis of measurement of consumers in using the services of physical evidence, empathy, reliability, responsiveness and assurance as well as the things that are important in determination of the consumer decision choosing banking services.
\end{abstract}

Keyword: Keywords: consumer decisions into customers

Gede Adi Wira Pradnyana | 96 dari 105 


\section{PENDAHULUAN}

Adopsi perbankan syariah dalam sistem perbankan nasional bukanlah semata-mata mengakomodasi kepentingan penduduk Indonesia yang mayoritas sebagian besar muslim, namun lebih kepada adanya faktor keunggulan atau manfaat lebih dari perbankan syariah dalam menjebatani ekonomi. Dalam sistem perbankan konvensional, selain berperan sebagai jembatan antara pemilik dana dan dunia usaha yang memerlukan dana, perbankan juga masih menjadi penyekat antara keduanya karena pada saat nasabah menabung atau kredit, bunga ditentukan di awal transaksi dan bank cenderung lebih diuntungkan. Bank tidak akan menanggung kerugian yang dialami dan tidak adanya timbal balik antara pemilik dana dan dunia usaha. Tidak demikian halnya sistem perbankan syariah keuntungan maupun kerugian akan ditanggung bersama, selain itu perbankan syariah juga menjadi manajer investasi, wakil, atau pemegang amanat dari pemilik dana atas investasi di sektor riil. Dengan demikian, seluruh keberhasilan dan resiko usaha secara langsung didistribusikan kepada pemilik dana dan pihak bank sehingga menciptakan suasana harmoni.

Bank syariah merupakan perbankan yang dalam sistem operasionalnya berdasarkan atas syariah. Sistem syariah yang digunakan yaitu kecenderungan untuk menggunakan dan menonjolkan nilainilai Islam. Salah satu contohnya jika dalam bank-bank konvensional sebutan untuk bank umum menggunakan sebutan "bunga bank" untuk istilah keuntungannya, maka dalam bank syariah keuntungan yang diperoleh nasabah itu disebut "bagi hasil" atau dalam istilah syariah disebut mudharabah. Sistem perbankan syariah memiliki kesamaan dengan sistem perbankan konvensional dalam hal mencari keuntungan dan pelayanan masyarakat dalam bisnis keuangan. Dengan demikian, antara bank konvensional dan bank syariah memiliki perbedaan dalam hal sistem balas jasa yang diberikan dan memiliki persamaan dalam hal pelayanan jasa kepada para nasabah. Berpegang pada prinsipprinsip balas jasanya masing-masing, kedua sistem perbankan ini bersaing bebas untuk merebut jutaan nasabah dengan berbagai strategi bisnis perbankan syariah tidak saja dilakukan oleh bank-bank yang murni berbasis syariah, tetapi hampir seluruh bank konvensional juga membuka bisnis perbankan syariah ini.

Banyaknya bisnis perbankan di Bali, masyarakat memiliki lebih banyak pilihan dalam menyimpan dananya. Baik bank syariah maupun bank konvensional menawarkan begitu banyak fasilitas pelayanan, promosi dan produk yang sangat memanjakan para nasabahnya, sehingga bank dapat menarik minat masyarakat untuk menabung di bank syariah. Kondisi persaingan bisnis perbankan ini mendorong setiap bank untuk mencari berbagai strategi pelayanan terbaik agar dapat menarik nasabah baru dan mempertahankan nasabah yang telah ada. Perbankan syariah sebagai alternatif dari sistem perbankan konvensional yang diharapkan dapat menggerakkan sektor riil dengan menampung berbagai kepentingan nasabah tidak saja umat muslim, tetapi juga bukan muslim. Pesatnya pertumbuhan perbankan syariah tidak 
menutup kemungkinan nasabah yang bukan muslim tertarik menginvestasikan dananya di bank syariah.

Kendati mayoritas nasabah muslim tidak menutup kemungkinan untuk bank syariah memiliki nasabah bukan muslim lebih banyak lagi dengan memberikan informasi yang lebih akurat, keuntungan serta nilai tambah yang akan didapat jika menjadi nasabah. Sebagian besar nasabah melihat bahwa nilai tambah bank syariah adalah lebih halal dan selamat, lebih menjanjikan untuk kebaikan akhirat, dan juga lebih berorientasi menolong antar sesama dibandingkan dengan bank konvensional. Kendati secara prinsip bank syariah memiliki nilai tambah dan keuntungan dalam hal bagi hasil atau mudharabah, namun dalam realitasnya Bank syariah menghadapi beberapa kendala dalam menghimpun calon nasabah bukan muslim. Kelemahan ini diduga karena terbatasnya pemahaman masyarakat mengenai kegiatan usaha jasa keuangan perbankan syariah. Bank syariah dituntut untuk lebih gencar dan berani membuka diri guna terus meningkatkan sosialisasi kepada masyarakat luas terutama dalam menumbuhkan kesadaran bahwa perbankan syariah tidak hanya ditujukan pada masyarakat muslim saja, tetapi masyarakat bukan muslim juga bisa menikmati pelayanan jasa bank syariah.

Secara teoritis dalam memilih bank nasabah akan memperhatikan dan mempertimbangkan faktor-faktor tertentu untuk memutuskan menggunakan layanan jasa perbankan. Faktor-faktor yang mempengaruhi konsumen dalam menggunakan jasa, yaitu kualitas pelayanan. Menurut (Tjiptono, 1997) "kualitas pelayanan adalah keunggulan yang diharapkan dan pengendalian atas tingkat keunggulan tersebut untuk memenuhi keinginan pelanggan". Untuk mengukur kualitas pelayanan sebagai dasar pengukuran konsumen dalam menggunakan jasa yaitu tangible, emphaty, reability, responsiveness dan assurance. Nasabah akan mempertimbangkan faktor-faktor tersebut untuk mencari kepuasan dalam menyimpan dananya di bank. Konsumen dalam perilakunya akan mencari kepuasan yang maksimal dalam memenuhi kebutuhannnya. Untuk itu dari sisi bank syariah harus dapat membaca peluang ini serta dapat segera mengidentifikasikan kebutuhan dan keinginan konsumen, karena apa yang dibeli, berapa banyak yang dibeli, dimana membeli, dan kapan membeli, akan tergantung kepada prilaku konsumen mengenai produk-produk yang dibutuhkan. Oleh karena itu, perilaku konsumen akan mempengaruhi keputusan pembelian terhadap suatu produk tertentu. Bank Syariah Mandiri diharapkan dapat mengetahui cara-cara yang akan dilakukan perusahaan untuk dapat memenuhi kebutuhan dan keinginan nasabah. Konsumen mempunyai alasan-alasan tertentu atau faktor-faktor yang mempengaruhi mereka untuk mengambil keputusan dalam menetapkan pilihan pada bank syariah.

\section{PEMBAHASAN}

Banyak ahli berpendapat tentang pengertian keputusan konsumen. Menurut Suprapti (2010) menjelaskan perilaku konsumen adalah "suatu studi tentang individu, kelompok, atau organisasi dan proses yang mereka gunakan untuk memilih, mendapatkan, 
menggunakan dan membuang produk jasa, pengalaman, atau gagasan untuk memenuhi kebutuhan dan dampak dari proses itu pada konsumen dan masyarakat". Menurut Setiadi (2010) ada empat komponen penting yang merupakan inti pengertian perilaku konsumen adalah 1) perilaku konsumen melibatkan berbagai aktivitas, baik yang sifatnya mental, emosi, dan fisik. Berfikir merupakan satu aktivitas mental, misalnya pengolahan informasi yang melibatkan memori otak ketika seseorang menerima suatu stimuli pemasaran. Aktivitas emosi menyangkut evaluasi terhadap suatu produk atau jasa sehingga menimbulkan perasaan senang atau tidak senang terhadap produk atau jasa tersebut. Aktivitas fisik misalnya, kegiatan memilih atau memutuskan satu produk yang akan dibeli di antara beberapa produk yang tersedia di pasar, 2) perilaku konsumen terjadi karena didasari motif tertentu. Setiap tindakan konsumen dilakukan untuk mencapai tujuan, yaitu memuaskan suatu kebutuhan atau keinginan, 3) perilaku konsumen menunjukan sebuah proses yang berkesinambungan, sejak konsumen belum melakukan pembelian, saat pembelian, dan setelah pembelian, 4) Konsumen merupakan pusat perhatian utama. Istilah konsumen digunakan untuk menjelaskan dua jenis entitas konsumsi yaitu konsumen perorangan dan konsumen organisasi. Pembelian bisa dilakukan oleh individu ataupun organisasi. Karena itu konsumen sering pula disebut sebagai unit pembelian.

Konsumen mengambil banyak macam keputusan membeli setiap hari. Perilaku konsumen menyangkut masalah keputusan yang diambil seseorang dalam persaingannya dan penentuan untuk mendapatkan dan mempergunakan barang dan jasa. Dalam persaingan usaha yang semakin ketat hampir setiap perusahaan mempelajari keputusan membeli konsumen secara rinci untuk menjawab pertanyaan mengenai apa yang dibeli konsumen, dimana mereka membeli, bagaimana dan berapa banyak mereka membeli, serta mengapa mereka membeli.

Pengambilan keputusan setiap konsumen atau individu berbeda-beda, tergantung pada keputusan pembelian. Keputusan untuk membeli pasta gigi, raket tenis, komputer pribadi, mobil, dan keputusan untuk penggunaan jasa akan sangat berbeda. Pembelian barang atau jasa yang rumit dan mahal mungkin melibatkan lebih banyak pertimbangan pembeli. Menurut Prasetijo (2005) ada empat perilaku konsumen berdasarkan tingkat keterlibatan pembeli dan tingkat perbedaan merek 1) perilaku pembelian yang rumit terdiri dari tiga tahap. Tahap pertama, pembeli mengembangkan keyakinan tentang produk tertentu. Tahap kedua, setelah pembeli mengembangkan keyakinan tentang suatu produk maka pembeli akan membangun sikap tentang produk tersebut. Tahap ketiga, pada tahap ini setelah pembeli dapat membangun sikap tentang suatu produk maka pembeli membuat pilihan pembelian yang cermat. Konsumen terlibat dalam perilaku pembelian yang rumit apabila mereka sangat terlibat dalam pembelian dan sadar adanya perbedaan yang besar antar merek. Perilaku pembelian yang rumit lazim terjadi apabila produk yang akan dibeli harganya mahal, jarang dibeli, beresiko dan sangat mengekspresikan diri, seperti membeli mobil mewah dan membeli rumah, 2) 
perilaku pembelian yang mengurangi ketidaknyamanan terdiri dari tiga tahap. Tahap pertama, pada tahap ini konsumen melakukan suatu tindakan pembelian dengan cara berkeliling untuk mempelajari merek yang tersedia. Tahap kedua, setelah konsumen mempelajari merek yang tersedia di dalam pasar maka konsumen akan memperoleh keyakinan terhadap suatu merek. Keyakinan ini dapat berupa keyakianan untuk menerima atau menolak barang dengan merek tertentu. Tahap ketiga, pada tahap ini setelah konsumen memperoleh keyakinan terhadap suatu merek maka konsumen akan melakukan suatu sikap terhadap merek tersebut. Sikap ini berupa keputusan konsumen untuk membeli atau tidak membeli barang dengan merek tersebut. Pada saat konsumen telah melakukan pembelian suatu barang dengan merek tertentu, konsumen akan mengalami ketidaknyamanan karena konsumen merasakan ada fitur yang tidak mengenakkan dari merek tesebut atau karena mendengar berita yang menyenangkan mengenai merek lain, sehingga konsumen akan kembali menggali informasi mengenai merek lain itu, 3) perilaku pembelian yang rutin dan biasa terjadi pada pembelian dengan kondisi keterlibatan konsumen yang rendah dan terdapat perbedaan antar merek yang kecil. (Kotler, 2005: 222) "konsumen memiliki keterlibatan yang rendah dalam pembelian sebagian besar produk yang harganya murah dan sering dibeli oleh para konsumen". Misalnya dalam pembelian produk garam, konsumen akan pergi ke toko dan mengambil garam dengan merek tertentu. Apabila konsumen tetap mengambil merek yang sama pada pembelian garam di waktu berikutnya, maka hal itu disebabkan karena kebiasaan, tidak karena kesetian yang kuat terhadap merek tersebut, 4) Perilaku pembelian yang mencari variasi terjadi pada pembelian dengan kondisi keterlibatan konsumen yang rendah dan terdapat perbedaan antar merek yang besar, dalam situai pembelian dengan kondisi keterlibatan konsumen yang rendah dan terdapat perbedaan antar merek yang besar, konsumen sering melakukan peralihan merek dari merek satu ke merek yang lainnya. (Kotler, 2005: 222) "peralihan merek yang terjadi disebabkan karena konsumen mencari variasi, tidak disebabkan karena ketidakpuasan konsumen terhadap merek tersebut".

Menurut Jhon Sviokla (dalam Lupiyoadi, 2001) "faktor yang mempengaruhi konsumen dalam menggunakan jasa yaitu kualitas pelayanan". Kualitas Pelayanan adalah keunggulan yang diharapkan dan pengendalian atas tingkat keunggulan tersebut untuk memenuhi keinginan pelanggan (Tjiptono, 1997). (Lupiyoadi, 2001) mengatakan "untuk mengukur kualitas pelayanan sebagai dasar pengukuran konsumen dalam menggunakan jasa yaitu tangible, emphaty, reability, responsiveness dan assurance". 1) Bukti fisik (tangible) yaitu kemampuan suatu perusahaan dalam menunjukkan eksistensi kepada pihak eksternal. Penampilan dan kemampuan sarana dan prasarana fisik perusahaan dan keadaan lingkungan sekitarnya adalah bukti nyata dari pelayanan yang diberikan oleh pemberi jasa yang meliputi fasilitas fisik. Persepsi pelanggan terhadap suatu jasa dipengaruhi oleh suasana yang dibentuk oleh penataan ruang fasilitas jasa, oleh 
sebab itu keadaan lingkungan tempat jasa disampaikan merupakan aspek yang tidak boleh dilupakan. Perusahaan jasa perlu mengembangkan pemahaman akan respon pelanggan terhadap berbagai aspek tata letak fasilitas jasa (gedung, gudang, tempat parkir, jarak tempuh, letak perusahaan dan lain sebagainya) perlengkapan dan peralatan yang dipergunakan, 2) empati (Emphaty) yaitu memberikan perhatian yang tulus dan bersifat individual atau pribadi yang diberikan kepada para pelanggan dengan upaya memahami keinginan konsumen. Dalam hal ini perusahaan diharapkan memiliki perhatian dan pengetahuan tentang pelanggan, memahami kebutuhan pelanggan secara spesifik, serta memiliki waktu pengoprasian yang nyaman bagi pelanggan, 3) keandalan (reliability) yaitu kemampuan perusahaan untuk memberikan pelayanan sesuai dengan yang dijanjikan secara akurat dan terpercaya. Dalam hal ini kinerja perusahaan harus sesuai dengan harapan pelanggan yang berarti ketepatan waktu, pelayanan yang sama untuk semua pelanggan tanpa adanya kesalahan, sikap yang simpatik dan dengan akurasi yang tinggi, 4) ketanggapan (responsiveness), yaitu suatu kemauan untuk membantu dan memberikan pelayanan yang cepat (responsive) dan tepat kepada pelanggan, dengan penyampaian informasi yang jelas. Penyampaian informasi sangat penting diterapkan perusahaan dalam membantu konsumen agar tidak terjadi adanya kesalahan informasi yang diterima konsumen terhadap perusahaan. Perlu adanya kesedian pegawai untuk membantu kesulitan konsumen, jika terjadi kesulitan konsumen dalam menggunakan jasa perusahaan, maka pegawai di sini berfungsi untuk membantu konsumen dalam menyelesaikan kesulitan yang dihadapi oleh konsumen, 5) jaminan (assurance), yaitu kemampuan perusahaan dan perilaku staf dalam menanamkan rasa percaya dan keyakinan kepada para konsumennya. Assurance mencakup tentang pengetahuan, kesopan santunan, dan bebas dari bahaya, resiko ataupun keragu-raguan untuk menumbuhkan rasa percaya para pelanggan kepada perusahaan.

Perbankan syariah memiliki keunikan tersendiri jika dibandingkan perbankan konvensional. Menurut UU No.10 tahun 1998 mengenai pengertian perbankan, bank adalah usaha yang menghimpun dana dari masyarakat dalam bentuk simpanan dan menyalurkannya kepada masyarakat dalam bentuk kredit dan atau bentukbentuk lainnya. Menurut Undangundang No. 10 tahun 1998 bank syariah adalah bank umum yang melaksanakan usaha berdasarkan prinsip syariah yang dalam kegiatannya memberikan jasa dalam lalu lintas pembayaran. Prinsip syariah adalah aturan perjanjian berdasarkan hukum Islam antara bank dengan pihak lain untuk penyimpanan dana dan atau pembiayaan kegiatan usaha atau kegiatan lainnya yang sesuai dengan syariah. Dijelaskan lebih lanjut pada Pasal 1 Undang-undang nomor 10 tahun 1998 menjelaskan bahwa prinsip syariah adalah aturan perjanjian berdasarkan hukum Islam antara bank dan pihak lain untuk penyimpanan dana dan atau pembiayaan kegiatan usaha, atau kegiatan lainnya yang dinyatakan sesuai dengan syariah, antara lain pembiayaan 
berdasarkan prinsip bagi hasil (mudharabah), pembiayaan berdasarkan prinsip penyertaan modal (musharakah), prinsip jual beli barang dengan memperoleh keuntungan (murabahah), atau pembiayaan barang modal berdasarkan prinsip sewa murni tanpa pilihan (ijarah) atau dengan adanya pilihan pemindahan kepemilikan atas barang yang disewa dari pihak bank oleh pihak lain (ijarah waiqtina). Secara umum, menurut Wiroso (2009) fungsi bank syariah berbeda dengan fungsi perbankan konvensional. Bank konvensional berfungsi sebagai intermediasi dan jasa keuangan sedangkan fungsi perbankan syariah yaitu sebagai 1) manajer investasi, 2) investor, 3) jasa keuangan, dan 4) fungsi sosial. 1) Fungsi bank syariah sebagai manajer investasi, memiliki kemiripan dengan perusahaan reksa dana. Fungsi perbankan syariah sebagai manajer investasi adalah bahwa bank syariah tersebut merupakan manajer investasi dari pemilik dana yang dihimpun, besarkecilnya pendapatan (bagi hasil) yang diterima oleh pemilik dana yang dihimpun sangat bergantung pada keahlian, kehati-hatian dan profesionalisme dari bank syariah. Fungsi manajer investasi ini tidak dimiliki oleh perbankan konvensional karena perbankan konvensional menggunakan sistem bunga sebagai keuntungan yang diberikan bank kepada nasabah. Jadi, bunga yang diterima nasabah akan mengalami fluktuasi setiap bulannya akibat nilai tukar rupiah terhadap dolar, dan bunga yang diterima nasabah setiap bulannya pun akan berbeda-beda. Bank syariah berpegang pada prinsip profit and loss sharing (bagi untung dan bagi rugi).
Bank syariah tidak membebankan bunga, melainkan mengajak partisipasi dalam bidang usaha yang didanai. Para deposan juga sama-sama mendapat bagian dari keuntungan bank sesuai dengan rasio yang telah ditetapkan sebelumnya. Dengan demikian ada kemitraan antara bank syariah dengan para deposan di satu pihak dan antara bank dan para nasabah investasi sebagai pengelola sumber dana para deposan dalam berbagai usaha produktif di pihak lain. Sistem ini berbeda dengan bank konvensional yang pada intinya meminjam dana dengan membayar bunga pada satu sisi neraca dan memberi pinjaman dana dengan menarik bunga pada sisi lain. Kompleksitas perbankan syariah tampak dari keragaman dan penamaan instrumen-instrumen yang digunakan serta pemahaman dalil-dalil hukum Islamnya. Perbankan Syariah memberikan layanan bebas bunga kepada para nasabahnya, pembayaran dan penarikan bunga dilarang dalam semua bentuk transaksi. Dengan demikian, fungsi perbankan syariah sebagai manajer investasi berbeda dengan fungsi perbankan konvensional sebagai perantara pihak yang kelebihan dana dan pihak yang kekurangan dana. Fungsi sebagai manajer investasi menghadapi risiko dan ketidakpastian yang lebih besar dibandingkan fungsi sebagai perantara keuangan, 2) fungsi investor dalam bank syariah mencakup penyaluran dana baik dalam prinsip bagi hasil (mudharabah dan musyarakah), prinsip ujroh (ijarah dan ijarah muntahia bittamlik) maupun prinsip jual beli (murabahah, salam, dan salam parallel, istishna, dan istishna paralel) bank syariah berfungsi sebagai investor sebagai pemilik dana. Oleh karena 
sebagai pemilik dana, maka dalam menanamkan dana dilakukan dengan prinsip-prinsip yang telah ditetapkan dan tidak melanggar syariah, ditanamkan pada sektor-sektor produktif dan mempunyai risiko yang sangat minim. Penerimaan pendapatan dan kualitas aktiva produktif yang sangat baik menjadi tujuan yang penting dalam penyaluran dana, karena pendapatan yang diterima dalam penyaluran dana inilah yang akan dibagikan kepada pemilik dana (deposan atau penabung mudharabah). Jadi fungsi ini sangat terkait dengan fungsi bank syariah sebagai manajer investasi. Bank-bank syariah menginvestasikan dana yang disimpan pada bank tersebut (dana pemilik bank maupun dana rekening investasi) dengan menggunakan alat investasi yang sesuai dengan syariah. Investasi yang sesuai dengan syariah tersebut meliputi akad murabahah, sewa-menyewa, musyarakah, akad mudharabah, akad salam atau istishna', pembentukan perusahaan atau akuisisi, pengendalian atau kepentingan lain dalam rangka mendirikan perusahaan, memperdagangkan produk, dan investasi atau memperdagangkan saham yang dapat diperjual belikan atau real estate. Keuntungan dibagikan kepada pihak yang memberikan kontribusi dana setelah bank menerima bagian keuntungan mudharibnya yang sudah disepakati antara pemilik rekening investasi dan bank sebelum pelaksanaan akad. Fungsi ini dapat dilihat dalam hal penyaluran dana yang dilakukan bank syariah, baik yang dilakukan dengan mempergunakan prinsip jual beli maupun dengan prinsip bagi hasil, 3) fungsi jasa keuangan dalam bank syariah dapat juga menawarkan berbagai jasa keuangan lainnya berdasarkan upah (fee based) dalam sebuah kontrak perwakilan atau penyewaan. Contohnya garansi, transfer kawat, $L / C$, dan sebagainya, 4) fungsi sosial pada perbankan syariah, mengharuskan bank melaksanakan jasa sosial, bisa melalui dana qardh (pinjaman kebajikan), zakat, atau dana sosial yang sesuai dengan ajaran Islam. Konsep perbankan syariah juga mengharuskan bank memainkan peran dalam pengembangan sumber daya insani dan menyumbang dana bagi pemeliharaan serta pengembangan lingkungan hidup. Prinsip yang dijalankan dalam melaksanakan operasional bank syariah sebagai berikut 1) prinsip keadilan, tercermin dari penerapan imbalan atas dasar bagi hasil dan pengambilan margin keuntungan yang telah disepakati oleh bank dan nasabah, 2) prinsip kesederajatan, bank syariah menempatkan nasabah penyimpan dana, nasabah pengguna dana, maupun bank pada kedudukan yang sama dan sederajat. Hal ini tercermin dalam hak, kewajiban, resiko, dan keuntungan yang berimbang di antara nasabah penyimpan dana, nasabah pengguna dana, maupun pihak bank, 3) prinsip ketenteraman, produk-produk bank syariah telah sesuai dengan prinsip dan kaidah muamalah Islam, antara lain tidak ada unsur riba dan menerapkan zakat harta. Dengan demikian nasabah merasakan ketenteraman lahir dan batin. Perbedaan fungsi dan prinsip antara bank konvensional dengan bank syariah berdampak pada persaingan antar bank yang sangat ketat. Banyak bank kini menawarkan berbagai keuntungan dan kemudahaan dalam menggunakan jasa perbankan, misalkan saja kemudahaan 
bertransaksi dengan menggunakan fasilitas electronic banking seperti mobile banking, internet banking, bahkan ada bank yang menawarkan rekening nomor ponsel agar lebih mudah melakukan transaksi transfer dana hanya dengan menggunakan nomor ponsel. Mengetahui perkembangan zaman saat ini sangat canggih, maka perusahaan yang bergerak di bidang jasa ini harus memahami kebutuhan nasabah ataupun calon nasabahnya dalam memilih bank dengan baik. Oleh karena itu pihak manajemen bank harus mengetahui tentang proses penilaian informasi terhadap pemilihan suatu bank dari calon nasabahnya. Untuk itu, menurut Kasmir (2000) keputusan pemilihan bank didasarkan kepada 1) karakteristik bank, bank sebagai lembaga kepercayaan berperan khusus dalam menghimpun dana masyarakat dan memobilisasikan dana dari masyarakat untuk disalurkan dalam bentuk kredit dan pembiayaan lain kepada dunia usaha, bank berperan khusus dalam penciptaan uang dan mekanisme sistem pembayaran dalam perekonomian. Keberadaan perbankan memungkinkan berbagai transaksi keuangan dan ekonomi dapat berlangsung lebih cepat, aman, dan efisien, 2) kesehatan bank, pemberian bobot pada kepentingan pada ciri-ciri yang relevan di mana banyak calon nasabah lebih mementingkan pada tingkat kesehatan suatu bank. Hal ini sangat penting, karena tingkat likuiditas bank akan dipertaruhkan saat terjadi inflasi, karena banyak bank yang tidak bisa bertahan saat tingkat inflasi meningkat, 3) kepercayaan akan merek bank persepsi nasabah terhadap suatu merek tertentu dipengaruhi oleh sosial individu nasabah, karena banyak informasiinformasi yang diperoleh calon nasabah didasarkan atas rekomendasi dari rekan atau kolega, padahal hal ini kembali kepada kepentingan individu masingmasing dalam memutuskan memilih merek bank untuk disesuaikan dengan kebutuhan. Perbedaan fungsi dan prinsip antara bank konvensional dan bank syariah menyebabkan keputusan konsumen menggunakan jasa perbankan pun berbeda-beda. Menurut Lupiyoadi (2001) ada lima determinan kualitas jasa yang dapat dijadikan pijakan dalam memilih penyedia jasa, meliputi 1) bukti fisik, 2) empati, 3) kehandalan, 4) ketanggapan, dan 5) jaminan. Kelima determinan tersebut dapat mewakili prinsip-prinsip pada bank syariah dan faktor penentu konsumen dalam menggunakan jasa perbankan, diantaranya 1) bukti fisik, yaitu penampilan fasilitas fisik, peralatan serta materi komunikasi yang menunjukkan citra dan eksistensi bank yang menjadi bukti nyata dalam memberikan pelayanan yang terbaik kepada nasabah. Berdasarkan uraian di atas dapat ditarik simpulan bahwa fisik perbankan meliputi kepercayaan akan merek bank dipengaruhi oleh sosial individu nasabah, karena kemungkinan informasi terhadap fisik dan merek bank direkomendasi oleh rekan atau kolega untuk dijadikan pertimbangan dalam memilih jasa perbankan, 2) empati, yaitu kesediaan karyawan untuk peduli dan memberikan perhatian bagi pelanggan dan memahami kebutuhan pelanggan secara spesifik, serta memiliki waktu pengoprasian yang nyaman bagi pelanggan, 3) kehandalan, yaitu kemampuan bank untuk melaksanakan jasa yang dijanjikan dengan terpercaya dan akurat, pelayanan yang sama untuk 
semua pelanggan tanpa kesalahan. Berdasarkan uraian di atas dapat ditarik simpulan bahwa karakteristik bank dan prinsip keadilan perbankan syariah termasuk dalam faktor kehandalan, tercermin pada kemampuan bank melaksanakan berbagai transaksi keuangan secara efisien dan melaksanakan perjanjian yang telah disepakati oleh bank dan nasabah mengenai penerapan imbalan atas dasar bagi hasil dan pengambilan margin keuntungan serta resiko kerugian secara terpercaya dan akurat, 4) daya tanggap, yaitu kemauan karyawan untuk membantu pelanggan serta memberikan jasa yang cepat dan tepat kepada pelanggan, dengan penyampaian informasi yang jelas sehingga tidak terjadi adanya kesalahan informasi yang diterima pelanggan terhadap perusahaan mengenai penyetaraan hak dan kewajiban yang dilakukan pihak bank serta nasabah atau penyimpan dana. Berdasarkan uraian, dapat ditarik simpulan bahwa prinsip kesederajatan perbankan syariah termasuk dalam faktor daya tanggap karena antara bank dan nasabah mempunyai kedudukan yang sama dan sederajat di dalam pembagian keuntungan dan resiko kerugian, 5) jaminan, yaitu pengetahuan dan kesopanan karyawan dan kemampuan mereka untuk menimbulkan kepercayaan dan keyakinan terhadap nasabah.

\section{SIMPULAN}

Berdasarkan uraian, dapat ditarik simpulan bahwa kesehatan bank dan prinsip ketentraman perbankan syariah termasuk dalam faktor jaminan tercermin pada keyakinan bahwa bank mampu bertahan saat terjadinya inflasi maupun gejolak perekonomian yang mampu merugikan bank ataupun nasabah. Pada prinsip ketentraman bank mampu menanamkan kepercayaan bahwa produk-produk bank syariah telah sesuai dengan prinsip dan kaidah muamalah Islam.

\section{DAFTAR PUSTAKA}

Antonio, M.S. .2001. Bank Syariah, dari Teori ke Praktik. Jakarta: Gema Insani

Kasmir, SE.,MM. 2000. Manajemen Perbankan Edisi 1. Jakarta: PT Rajagrafindo Persada

Kotler dan Armstrong. 2003. Prinsipprinsip Pemasaran Jilid 1 Edisi ke Delapan. Jakarta: Erlangga

Kotler, Philip. 2005. Manajemen Pemasaran Jilid 2 Edisi ke Sebelas. Jakarta: PT. Tema Baru

Lupiyoadi, Rambat. 2001. Manajemen Pemasaran Jasa Teori dan Praktek. Jakarta: Salemba Empat

Prasetijo, Ristiyanti dan John J.O.I Ihalauw. 2005. Perilaku Konsumen. Yogyakarta: Andi Offset

Setiadi, Nugroho J. 2010. Perilaku konsumen Edisi Revisi. Jakarta: Kencana Perenada Media Group

Suprapti, Sri. 2010. Perilaku Konsumen. Denpasar: Udayana University Press

Tjiptono, Fandy. 1997. Manajemen Jasa Edisi Kedua. Andi Yogyakarta: Yogyakarta

Wiroso, Muhammad Y. 2009. Akuntansi Perbankan Syariah. Jakarta: Trust Media 